\title{
Weathering the 'Long Wounded Year': livelihoods, nutrition, and changing political ecologies in the Mikea Forest Region, Madagascar
}

\author{
Amber R. Huff ${ }^{1}$ \\ University of Georgia, USA
}

\begin{abstract}
Researchers studying health, adaptability, and political economy have long been concerned with human health as a reflection of interpenetrating sociopolitical, economic, ecological, and bodily processes. However, understanding the production of health in the context of changing political ecologies remains underexplored and undertheorized. This article proposes a 'landscape framework' for understanding variation in health across social and geographic space in contexts characterized by sociopolitical, economic, and environmental change. The proposed framework draws on scholarship from political ecology, medical anthropology, and research on livelihoods vulnerability, and is applied to understand variation in nutritional status, a locally and analytically salient manifestation of livelihood vulnerability, observed among Mikea people living in three communities in rural southwestern Madagascar in 2009. Because of the conjunctural nature of livelihoods vulnerability during the research period, which residents of the region widely described in idiomatic terms as the baintao lava, or 'the long wounded year,' no particular variable, interaction, or local capability is sufficient to explain variation in experienced insecurities and associated nutritional patterns, nor to explain why changes in bodily manifestations of livelihoods vulnerability were observed across seasons of data collection. Rather than focusing on factors of linear causation, the proposed framework focuses attention on articulations among processes that are associated with long-term adaptability, exposure to acute stressors, and the capabilities of people to take action in response to perceived social and environmental challenges. By emphasizing process and articulation, the landscape framework allows the analytic integration of scales of socio-ecological interaction, facilitates comparative analyses of vulnerability within regions, and demonstrates how the integration of ecological and social dimensions of experience can help to unmask processes that produce vulnerability and may contribute to resilience in a regional context.
\end{abstract}

Key words: Political ecology, health, vulnerability, food security, nutrition, adaptability, Madagascar, conservation, development

\section{Résumé}

Les chercheurs spécialistes des questions de santé, d'adaptabilité et d'économie politique s’intéressent depuis longtemps à la façon dont la santé donne à voir l'interpénétration des processus socio-politiques, économiques, écologiques et corporel. Néanmoins, la compréhension des questions de la santé en contexte de changements écologiques et politiques reste peu abordée d'un point de vue théorique. Cet article propose un cadre, un «landscape framework», pour appréhender les variations des questions de santé dans différents contextes socio-écologiques caractérisés par des processus de changement complexes. Le cadre proposé intègre des théories de l'écologie politique, de l'anthropologie médicale et des recherches sur la vulnérabilité des moyens de subsistance. Il nous sert, ici, de cadre explicatif aux variations de l'état nutritionnel, considérées comme une manifestation de cette vulnérabilité et observées lors d'une étude de terrain chez les

\footnotetext{
${ }^{1}$ Dr. A.R. Huff, Part-time Assistant Professor, Department of Anthropology, University of Georgia, USA. Email: ahuff123 "at" uga.edu. I acknowledge an NSF Graduate Research Fellowship, a Doctoral Dissertation Improvement Grant (DDIG) and supplemental funds from the Behavioral and Cognitive Sciences Division of the NSF (BCS 0817261) and a grant from the Fulbright Institute of International Education (IIE). I am especially thankful to the community leaders and residents who participated in this research, and Professors Tsiazonera and Jaovola Tombo of the Université de Toliara, Madagascar; Professor Bartelemy Manjakahery, director of the Centre de Documentation et Recherche sur l'Art et les Traditions Orals à Madagascar (CeDRATOM); and Patricia Hajasoa, Rolland Lahiniriko, Gervais Tanteley, Jean-Claude Alhayess, and Théodore Ramanovontsoa. Thanks to Patrick Huff, Dave Himmelfarb, Bram Tucker, and anonymous reviewers for their thoughtful comments. This paper was winner of the Eric Wolf Prize, Political Ecology Society, 2013.
} 
peuples Mikea de trois communautés rurales du Sud-ouest de Madagascar en 2009. 2009 est considérée par les habitants de la région comme la «baintao lava», ou «l'année longue blessée». Dans ce contexte particulier, aucune variable, interaction ou capacité locale n'a permis d'expliquer les variations observées dans les insécurités ressenties et les patterns nutritionnels associés, ni d'expliquer pourquoi des changements dans les manifestations corporelles de la vulnérabilité ont été observés au cours de deux saisons de nos observations de terrain. Plutôt que de se concentrer sur les facteurs de causalité linéaire, le cadre théorique proposé ici permet de se concentrer sur les articulations possibles entre processus d'adaptation à long terme, exposition à des facteurs aigus de stress et stratégies locales d'adaptation aux défis sociaux et environnementaux perçus. En soulignant ces processus et articulation, le cadre proposé rend possible l'analyse intégrée d'interactions socioécologiques à différentes échelles, facilite les analyses comparatives de la vulnérabilité dans diverses régions, et montre comment l'approche intégrée des dimensions écologiques et sociales peut aider à saisir les processus produisant de la vulnérabilité et contribue à la résilience dans un contexte régional.

Mots-clés: l'écologie politique; santé; vulnérabilité; sécurité alimentaire; nutrition; adaptabilité; Madagascar; conservation; développement

\section{Resumen}

Los investigadores que estudian la salud, la capacidad de adaptación, y la economía política han teorizado que la salud humana es un reflejo de interacciones entre los procesos sociopolíticos, económicos, ecológicos y corporales. Sin embargo, la comprensión de la producción de salud en el contexto de cambios en la ecología política sigue siendo poco conocido e insuficientemente estudiado. En este artículo se propone un "marco paisaje ' para la comprensión de la variación en la salud a través del espacio social y geográfico en los contextos caracterizados por el cambio socio-político, económico y ambiental. El marco propuesto se basa en la ecología política, la antropología médica y la investigación sobre los medios de subsistencia de la vulnerabilidad, y se aplica para entender la variación en el estado nutricional, una manifestación a nivel local y analíticamente relevante de la vulnerabilidad sustento, observado entre las personas de tres comunidades de Mikea en el suroeste rural de Madagascar en el 2009. Debido a la naturaleza coyuntural de los medios de subsistencia de la vulnerabilidad durante el período de investigación, en que los residentes de la región ampliamente describieron en términos idiomáticos como la "baintao lava" o "el año de largo heridos", ninguna variable en particular, ni la interacción, o la capacidad local han sido suficientes para explicar la variación en inseguridades experimentadas y los patrones nutricionales asociados, así como tampoco explicar el por qué no se observaron cambios en las manifestaciones corporales de los medios de subsistencia de la vulnerabilidad a través de la recolección de datos estacionales. En lugar de centrarse en los factores de causalidad lineal, el marco propuesto centra la atención en las articulaciones entre los procesos que se asocian a la capacidad de adaptación a largo plazo, la exposición a los factores de estrés agudo y las capacidades de las personas para tomar medidas en respuesta a la percepción de los desafíos sociales y ambientales. Enfatizando el proceso y la articulación, el marco paisaje permite la integración analítica de las escalas de interacción socio- ecológico, facilita el análisis comparativo de la vulnerabilidad dentro de las regiones, y demuestra la integración de las dimensiones ecológicas y sociales que la experiencia puede ayudar a desenmascarar los procesos que producen la vulnerabilidad y puede contribuir a la capacidad de recuperación en un contexto regional.

Palabras claves: Ecología política, salud, vulnerabilidad, seguridad alimentaria, nutrición, adaptabilidad, Madagascar, Conservación, Desarrollo 


\section{Introduction: the 'long wounded year' and conjunctural vulnerability in the Mikea Forest region}

Shortly after arriving in Toliara, the regional capital of Madagascar's southwestern province, colleagues from the Université de Toliara and I-a group of graduate students in sociology, human geography, and anthropology - completed final preparations to travel to villages and hamlets located in and near the Mikea Forest to conduct research on livelihood change, health, and the establishment of a new restrictive national park. It was late December, Litsake, normally the hot, rainy season in the southwest. We were in a hurry to pack the truck with our provisions and get on the road. If the seasonal rains were to arrive while we were en route, the national highway that we would follow to Antanimena before heading into the forest might become a muddy, impassible mess. The weather seemed to be on our side as we made our way to Vorehe, a former mission outpost-cum-rural market town located in woody savannah to the east of the Mikea Forest where we met our friend and guide, Gerré and chatted with friends and acquaintances about recent events.

On our first morning in Vorehe, Gerré made arrangements for his absence from home as we visitors from Toliara shared coffee with one of Gerré's younger cousins, Martin. As we listened to thump-thump of raw silk being processed across the yard, Martin caught us up on the news and gossip.

His daughter Rasoa was happily expecting her first child.

A nearby village had been collectively fined by people claiming to be 'forest police' for growing maize in swidden plots.

Many small villages on the forest edge had estalished night watches because armed bandits and cattle thieves were becoming increasingly problematic in the region.

The mayor of nearby Basibasy had received a letter from the government about the establishment of a titanium mine, and helicopters had been spotted surveying the titanium rich 'black sands' to the north and west.

When we asked what people knew about the new Mikea Forest National Park, Martin said that he didn't have much information, but insisted that people living in villages in the northern forest were whispering rumors about possible forced eviction. Between the establishment of the park and the new mines, said Martin, a lot of people believed that the Mikea Forest and some of the surrounding area had been sold to foreigners by the Malagasy state.

As we chatted, Gerré's elder uncle Dominic joined us and, after greetings, he joined the discussion and brought up the baintao. The phrase was unfamilar to me, so I asked Anja, one of the Toliarois researchers, to clarify. She explained in French, "The word bai, it's a wound like when someone is cut or has a broken bone. Tao is a year. So baintao is a 'wounded year' and Baba Domi is saying that this is one because it has been too dry and too hungry for too long, and people are getting very worried."

As we left Vorehe and travelled through the dusty region, passing from woody savanna where residents grew irrigated paddy rice and vegetables, through the hamlets and foraging camps built atop red dunes and dappled shade of the dry deciduous Mikea Forest, to the fishing villages, thorny shrubs, mudflats and shining white limestone sands of the western coast on the Mozambique channel, I learned more and more about this "wounded year," past wounded years, and why some people living in the region eventually began to call this particular wounded year the baintao lava, or "the long wounded year".

Complex social, ecological, and political processes affect how people make a living and whether or not that living is satisfying and sufficient to maintain health and wellbeing. In rural southwestern Madagascar, in oral histories and lived memory, wounded years are periods of exceptional hardship due to a broad range of insecurities related to livelihoods vulnerability. Ideal livelihood strategies are flexible and situational, strategically depend on mobility and diversification, and resemble what Batterbury (2001: 483) terms "productive bricolage", a strategy incorporating a range of agricultural, non-agricultural, subsistence and market-oriented activities based on seasonality, skill, opportunity, and market demand (see also Huff 2011: 87-92; Scoones 2009). Whether or not any given person or collective can access these elements and transform 
them into subsistence security depends on ecological conditions, the goals and decisions of individual producers, and how social relationships and institutions mediate access to resources and streams of income and sustenance (Ellis 2000: 291; Yaro 2004: 27).

The long wounded year was a period of "conjunctural vulnerability" (Ribera and Hausman-Muela 2011: 110), in which residents of the region navigated a confluence of both long-standing and novel challenges. Long-term processes included ecological risk, regional social and economic inequalities, and nonfunctioning transportation and communications infrastructure. More recent challenges were associated with socio-environmental changes like prolonged drought and increasing climatic unpredictability, new changes to entitlements and to the accessibility of natural resources and markets, and widespread insecurities associated with processes of internal state territorialization and national-scale political and economic crises (Huff 2011).

In regional context, the 'wounded year' engendered wounded bodies as many people's adaptability in the face of compounded challenges became overburdened. The literal embodiment of vulnerabilities manifested across the region as high risk of undernutrition, but exposure to this risk was variable across the region, patterned both spatially and socially. Because of the conjunctural nature of livelihoods vulnerability in the region, no particular variable, interaction, or local capability is sufficient to explain variation in experienced insecurities and associated nutritional patterns, or to explain why changes in bodily manifestations of livelihoods vulnerability were observed between two seasons of data collection.

Researchers studying health and adaptability have long been concerned with variation in human health as a reflection or embodiment of interpenetrating sociopolitical, economic, ecological, and bodily processes. However, understanding the production of health relationally, at the intersection of these processes, remains under-explored and under-theorized. This is true despite integrative work at the nexus of health, political economy, and ecology since the 1970s (early examples include Hughes and Hunter 1970; Meade 1976; Turshen 1977), and continuing calls through the 1990s and 2000s by anthropologists, geographers, and scholars in allied fields for the development of new frameworks for conceptualizing nature-society-health interrelationships (Baer 1996; King 2010; King and Crews 2013; Leatherman 2005; Mayer 1996, 2000; Singer 1996, 2013).

This article proposes a landscape approach that extends and clarifies models for applying political ecological analysis to questions of the production of health, vulnerability, and resilience in the 'relational spaces' formed by cross-scalar social, economic, and human-ecological processes and relationships. Rather than focusing on factors of linear causation, the proposed framework approaches vulnerability from a contextual perspective and focuses analytic attention on articulations among processes that are associated with long-term adaptability, exposure to acute stressors, and the capabilities of people to take action in response to perceived social and environmental challenges.

I use this analytic approach to demonstrate how differences in setting and historical experience contribute to intraregional variation in a locally and analytically salient manifestation of livelihoods vulnerability: the nutritional status of adults and children.

Participants in this research include Mikea, Vezo-Mikea, and Masikoro-Mikea people living in three villages in the Mikea Forest region, an arid but ecologically heterogeneous rural region in southwestern Madagascar. Information presented in this article was collected using policy analysis, interviews, focus groups, ethnographic observation, and anthropometric methods over approximately eleven months in 2008 and 2009, and contributes to a stream of ethnographic research on livelihoods, poverty, and environmental policy carried out in the Mikea Forest region since 2006 (Tucker et al. 2011; Huff 2011; Huff 2012).

In the three-site comparison that I present, the most ecologically resilient and nutritionally secure community was the one in which geographic proximity to markets, social resources, and secure collective rights to land and water allow residents to maintain multiple livelihoods, creatively mixing some market production, foraging activities, subsistence farming, and wage labor. This mixed 'productive bricolage' livelihood strategy facilitated adaptability to drought, new restrictive environmental policies, and national political and economic crises, on a community level produced more security than observed in either the more market-dependent or the more forest-dependent communities. I also found that, despite pervasive popular and policy narratives that depict forest-based Mikea people as a culturally distinct population of foragers living in adaptive ecological balance with the forest environment, adults and children living in the forest community 
experienced significantly more livelihoods vulnerability, poorer nutritional health, and higher degrees of sociopolitical insecurity than participants living in other sites.

These results highlight both the conceptual contributions and the policy relevance of a landscape approach. By emphasizing ecological/biophysical and critical/social dimensions of changing political ecologies, determining how different conjunctures among similar forces are patterned socially and spatially, and determining how these patterns are associated with variability in health and wellbeing, the landscape approach can be used to analytically unmask and compare processes that produce vulnerability and contribute to resilience in dynamic contexts. This approach also provides a means to evaluate and inform policy decisions and develop empirically based alternatives to 'received wisdoms' about gender, identity, markets, economic behavior, and human-environment relationships that may erroneously guide policies and practice in conservation and development contexts.

\section{A landscape approach to vulnerability: linking scale, process, and perspective in the study of health and wellbeing}

Since the 1990s, scholars working at the intersection of society, ecology, and the body have called for the development of new, synthetic frameworks for understanding nature-society-health interrelationships. Across disciplinary literatures, common themes are apparent. One common theme is a call for a broad conception of health and acknowledgement that particular health threats exist not in isolation of others but in a dynamic milieu conditioned by historical socio-ecological contexts (Mayer 1996, 2000; Singer 1996; 2013). A second common theme is a broad critique of largely apolitical adaptationist approaches in human and disease ecology and the suggestion that this critique can best be met through the integration of health studies with political ecological analyses (Baer 1996; Leatherman 2005; Mayer 1996; Singer 1996; Tehrani 2010). This is related to a broader critique among political ecologists calling for engagement that crosses 'natural' and 'social' sciences to advance a robust integrated realm of theory and practice which can unmask and be applied to processes that shape differential vulnerability to disease, ecosystem functioning, and agency across time and space. As applied to health studies, this specifically includes a need for increased integrative attention to material and discursive linkages (related to issues of framing, positionality, representation, and discourse) that comprise reciprocal health-society-environment relationships (Baer 1996; King and Crews 2013; Leatherman 2005).

King and Crews (2013) identified primary challenges that should be integral to ongoing work linking political ecologies and a broad conception of human health. One challenge is the identification of ways to analytically integrate scales of socio-ecological interaction and conceptually situate health at the "forefront of multiple levels of organization [including horizontal and vertical relationships] of health bearers" (p.281). A second related challenge for scholars working to advance the theorization and applicability of such frameworks is to conceptualize health at the scale of landscape, emphasizing dynamic relationships among health and changing possibilities for human-environment interaction including changing modes of governance and patterns of land use, land cover, climate, and demography (pp.284-285).

A few key orienting concepts were important to meeting these critiques and challenges and building a coherent framework for understanding variation in vulnerabilities in health across social and geographic space. These key concepts include landscape, region, adaptability, and health in the study of contextual vulnerability.

The first two concepts, landscape and region, relate to setting and the ways in which particular localities and social scales interact. Interactions involve material and social dimensions of lived and visualized terrain as well as subjective and intersubjective notions of place that are enmeshed within broader political economies and broader ecologies. A landscape approach provides an integrative means of envisioning the material and discursive processes that continuously condition context, the ways that 'places' are lived, embodied, and practiced in ways that are simultaneously place-based and extra-local (Batterbury 2001; Neumann 2011; Zimmerer 1999). A landscape approach is commensurate with a regional orientation in political ecology that explicitly links localized or place-based relationships to globalized processes through examining interactive effects across geographic scales and across hierarchies of socio-economic organization (Blaikie 1999; Blaikie and Brookfield 1987; Walker 2003). 
The next orienting concept is human adaptability in relation to a broad conceptualization of health. Departing somewhat from conventional understandings of adaptation in human ecology and human biology, a growing body of work oriented around the concept of 'human adaptability' broadens our understanding of environment to include not only ecological characteristics and changes, but also "the complex webs of social interactions which humans create and in which they are embedded" (Crooks et al. 2007: 669; Leatherman et al. 1993). In this expanded view, 'environment' is essentially a type of reciprocal relation. It is not simply that which surrounds humans and to which humans respond; environment is also that which is perceived, experienced, created, and acted upon. In this view, political, economic, and ecological experiences influence the availability of social and material resources. These experiences also pattern how exposure to stressors is distributed within and across human groups, and the possibilities for choices that people can and do make in response to a broad range of desires and socio-ecological challenges (Schell 1997: 67). Within this frame, I adopt the fundamental assumption that biology, the human body, and contextualized notions of health, illness, vulnerability, and wellbeing are deeply socialized, historicized, and reciprocal (Baer et al. 1986; Carney 2014; Levins and Lewontin 1985; Morgan 1987; Turshen 1977, 1984).

A final orienting concept is 'contextual vulnerability.' Vulnerability is a powerful heuristic that is broadly associated with the concepts of risk and human security, and is a key element of international discourses on adaptation, mediation, and resilience in the face of social and environmental change (O'Brien et al. 2007). In the literature, two primary perspectives on vulnerability stem from different ways of conceptualizing and framing response to social and environmental change. These perspectives are 'outcome' vulnerability and 'contextual' vulnerability (Brooks et al. 2005; O'Brien et al. 2005, 2007; Kelly and Adger 2000). An outcome approach, with roots in hazard-oriented research on disaster risk, conceptualizes vulnerability as the "end-point of a sequence of analyses", involving identification of factors of risk exposure, projections of risk, and the identification of adaptive options (Sumner and Mallett 2011; Eakin and Luers 2006; Kelly and Adger 2000: 327).

In contrast, contextual approaches "...are more likely to characterize vulnerability as a dynamic socialenvironmental state that limits capacities, enhances sensitivities or increases exposure to particular threats" (Casale et al. 2009: 159). This perspective conceptually complements political-ecological approaches; vulnerability is not something that happens as the end result of a linear process, but is rather a starting point for analyses, an emergent characteristic of socio-ecological systems that is generated by multiple factors and processes as they articulate and manifest in variable and context-specific ways (Few 2007; Few and Tran 2010; O'Brien et al. 2007).

Existing models of contextual vulnerability incorporate aspects of these key concepts in different ways and to different degrees. The Space of Vulnerability approach, first proposed by Watts and Bohle (1993), and the Multiple-Stressor approach developed by researchers associated with the Southern Africa Vulnerability Initiative (SAVI), have been particularly influential in developing the landscape approach to vulnerability (Casale et al. 2009; O'Brien et al. 2007; O'Brien et al. 2009; Watts and Bohle 1993).

The Space of Vulnerability is a socio-spatial approach to 'mapping' associations among social, political, economic, and structural-historical constraints that function as 'coordinates' of vulnerability (Crooks et al. 2007; Leatherman 2005; Watts and Bohle 1993; Yaro 2004). It helps us to conceptualize the production of dynamic vunerability as a characteristic of context, and to explore the causal structure of vulnerability in relation to changing entitlements, poverty, and hunger. It does this by identifying and emphasizing synergies among different forms of risk that can influence human wellbeing (Watts and Bohle 1993). A particular contribution of SAVI's Multiple-Stressor approach is that it allows us to overcome the problem of comparison across sites by directing analytical attention not to a set of associations among predictive variables and outcomes, but rather to interactions and synergies among linked long-term and short term processes, akin to the coordinates of vulnerability mentioned above, that comprise context and that shape the significance and effects of exposure to stressors (Casale et al. 2009).

Both of these models treat vulnerability as a locally manifest characteristic of linked ecological, institutional, and economic arrangements that originate in, cross, and influence conditions on different social scales and affect people's ability to perceive changes and act in order to cope with change (Adger 2006; Baro and Deubel 2006; Casale et al. 2009; O'Brien et al. 2007; O'Brien et al. 2009). Both of these models 
contribute to 'mapping' the dynamic enmeshment of global and local, and conceptualizing how, in the context of rapidly changing political ecologies, 'spaces of vulnerability' are patterned by historically conditioned social relationships that can focus risk or factors of resilience on different groups of people, ecosystems, or institutions (Leatherman 2005).

Rather than replicating these models, the proposed landscape approach synthesizes, clarifies, and extends these models to further the applicability of political ecological theory to the study of health and social change. The proposed framework views vulnerability and resilience as emergent characteristics of lived context that emerges at the intersection or conjuncture of experience, capability, and constraint. It is a type of risky situationality produced through exposure to multiple potential stressors that can interact in ways that affect people's perception of and response to changes (Baro and Deubel 2006). In this frame, vulnerability is a dynamic "process of continual evolution" because the institutional and material factors that comprise the context of vulnerability are never static, but in a constant state of flux (Leicheinko and O'Brien 2002: 3). The approach focuses analytic attention on how different processes articulate and focus risk in different ways for different groups of people (Figure 1). Understanding how different processes articulate, are assessed by people, and are acted upon (including factors that constrain action) facilitates analyses of associations among cross-scalar processes that produce context, privileges local perceptions of risk and options for action, and can account for variability in experiences of vulnerability across populations and regions.

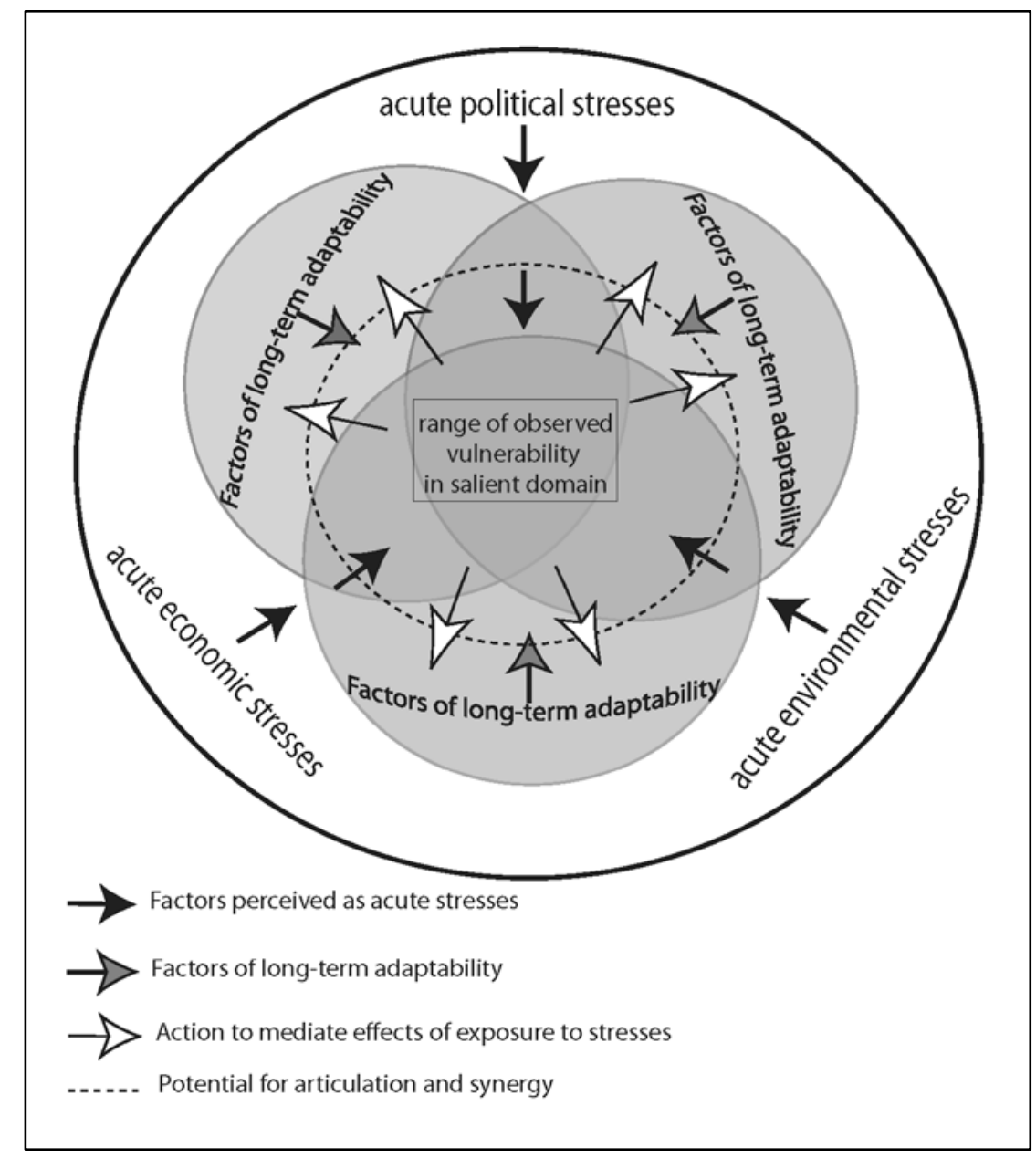

Figure 1: The context of vulnerability, comprised of linked environmental, sociopolitical, and economic processes that articulate with strategies associated with adaptability to long-standing challenges and opportunities, as well as with strategic actions and responses to acute stressors, crises, and shocks. 


\section{Cultural geography, norms of economy, and factors of dynamic change in the Mikea Forest region}

The Mikea Forest region lies east of the Mozambique Channel between the cities of Toliara and Morombe in southwestern Madagascar (Figure 2). City dwellers refer to this region, along with most of rural Madagascar, as Ambani'vohitse (below the hills), a term without geographic specificity but implying isolation from city centers and state infrastructure. The landscape of the Mikea Forest region is arid but ecologically heterogeneous, and three primary cultural identities, Mikea, Vezo, and Masikoro, are normatively associated with different local ecologies and primary livelihood activities. Mikea are described locally as "people of the forest", who have expert knowledge of the forest environment, forest-based horticulture, hunting, and foraging. Vezo are described as "people of the sea", experts in fishing and marine foraging on the reefs that hug the west coast. Masikoro are described as people of the savanna to the east of the Mikea Forest, who specialize in farming and herding.

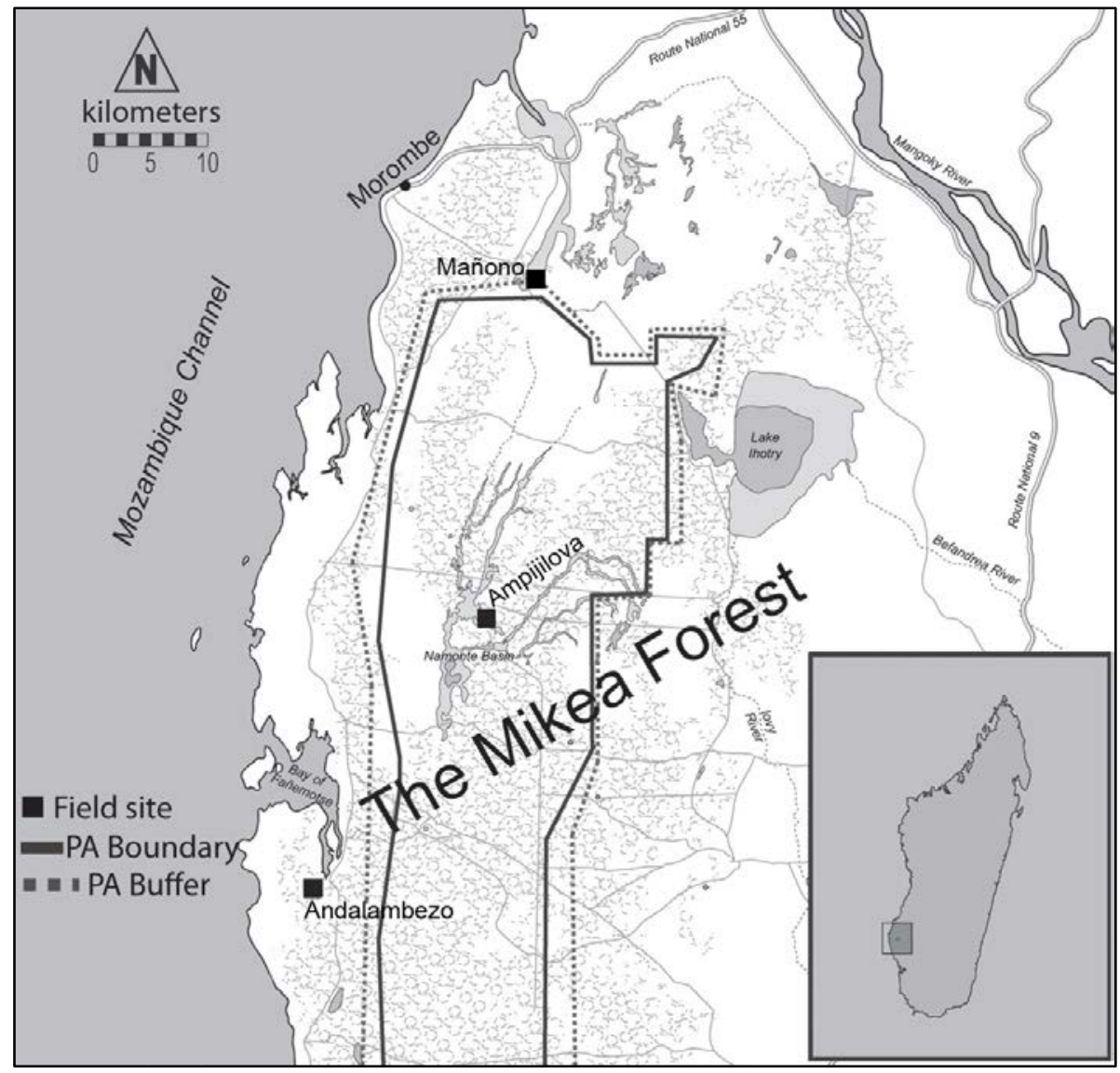

Figure 2: Map of the Mikea Forest region with field sites, protected area (PA) boundaries, and PA buffer zones indicated. Adapted by the author from maps by Bram Tucker and FTM/Madagascar National Parks (2009). Forest extent from 1994 Landsat images processed by James Yount.

Despite regional norms of identity, Mikea, Vezo and Masikoro are highly mobile and share common historical heritage (Tucker 2003: 199). Social identity is flexible, and is linked to local ecologies, historical memory, daily practice, and primary livelihood strategies (Yount et al. 2001). Because of this flexibility, most people who self-identify as Mikea frequently also identify as Vezo or Masikoro, alluding simultaneously to 
personal histories, to livelihood diversification, or historical migrations of particular groups of families, firazagna (patrilineal clans), or tariha (sub-lineages or clan 'branches'). As Poyer and Kelly (2000:168-169) observe, the individual identities of self-identifying Mikea people shift for various reasons, including avoidance of stigma or discrimination, as one moves between forest hamlets and larger villages (pp.168-169).

Like regional social identities, ideal livelihood strategies are flexible and situational. Mikea livelihoods incorporate mobility and diversification, and exploit a range of possible productive activities and relationships. In any given Mikea community, residents are likely to practice a combination of horticulture, animal husbandry, freshwater fishing, forest foraging, marine foraging, manufacturing, market commerce, and wage labor. Livelihood portfolios are most often diversified on an individual, not household, level, and tend to be oriented around distinct short-term and long-term goals.

Short-term goals revolve around meeting subsistence needs and avoiding acute impoverishment risks, which include hunger, interpersonal violence, theft (especially cattle theft), exploitation in commercial transactions, and exploitation by representatives of the state demanding bribes. Another short-term goal is to earn cash income in order to satisfy needs for goods and services beyond what individuals can do, produce, or harvest by their own labor. Neither having food nor having money alone can achieve long-term goals of Mikea livelihoods, but are rather 'invested' in pursuit of long-term goals.

Long-term goals include maintaining subsistence security by building a resilient stock of assets, resources, skills, and social relationships, and building multi-dimensional wealth. Wealth is reckoned in a number of ways that relate to amassing functional materials and entitlements, and in building healthy families primarily through having children, but also through marriage and establishing fictive kinship ties as well. Throughout the Mikea Forest region, livestock, and most importantly cattle, signify social status and clan membership, are necessary for bridewealth and for sacrifice in social ceremonies, and signify identity and relationships between the living people and deceased ancestors. For Mikea people living within the Mikea Forest proper, cattle have additional importance as a form of self-reproducing wealth that can be sold or traded in times of hardship.

Over the past several years the Mikea Forest region has increasingly become part of policy conversations among international environmental NGOs, bilateral and multilateral donor organizations, and national subsidiary agencies under Madagascar's National Office for the Environment (ONE). This interest was stimulated by national goals to increase the amount of forested land under legal protection in Madagascar, and justified citing a significant reduction in forest cover since the 1970s due to forest cutting and burning for pasturage, charcoal production, and especially for once-lucrative hatsaky, swidden maize production (Aubry and Ramaromisy 2003; Blanc-Pamard 2009; Du Puy and Moat 1998: 15; Durbin et al. 2006: 55; Milleville et al. 2001; Seddon et al. 2000). By the late 1990s, plans for a Mikea Forest protected area had coalesced. A blanket ban on hatsaky maize production in and near the Mikea Forest was put into effect, and this ban continues to be enforced over a decade later. As many small farmers have few commensurate alternatives to swidden maize production, an important source of calories and cash, the continued ban on hatsaky maize has had profound and rippling effects through the Mikea Forest region in terms of security of livelihoods, and security from crime and exploitation (Huff 2011, 2012).

Subsequent to the hatsaky maize ban, policy action has included the establishment of a large area of protection centered on the Mikea Forest in 2007 through the Mikea Forest Protected Area agreement, and the formal establishment of the restrictive Mikea Forest National Park in early 2009. Wide-ranging restrictions on land and other resource use, habitation, and access are justified based on two primary and antagonistic static stereotypes of rural subsistence-orented Malagasy people. The first stereotype presents forest-based Mikea as pristine foragers maintaining a lifestyle commensurate with the "ecologically noble savage" (Redford 1991), neither needing nor desiring economic or social opportunities beyond those afforded by a(n imagined) pristine and idyllic forest-based existence. In contrast, other Malagasy producers described as 'false Mikea' and 'migrants' are represented as encroaching on Mikea lands, endangering 'traditional' Mikea subsistence and spiritual practices by causing deforestation, introducing farming, currency, commerce, and consumer goods, and committing violent acts of theft (WWF 2003). People whom planners refer to as the 'autochtonous Mikea population' are exempt from these restrictions because, according to policy documents, "their traditional practices and exploitation of resources are in harmony with their natural habitat," and are considered 
compatible with the management objectives of the park (Repoblikan'i Madagasikara et al. 2010:9). Because no people living in the region actually resemble these policy narratives of identity and lifestyle, in practice these stereotypes justify outright exclusion of smallholders from forest resources, forest-based livelihood activites, and territory. ${ }^{2}$

But at the same time, limited funding and poor organizational capacity has resulted in a situation in which regulations are unpredictably or inconsistently enforced, and information regarding habitation rights and permitted uses of land and other natural resources is inaccessible to a majority of rural residents who depend on the Mikea Forest for livelihoods. The governance structure of the area surrounding Mikea National Park does not include substantive options for any local residents to participate in policy formulation or park governance (Wingen 2011:58). According to Wingen (2011), the lack of participation "as well as the seemingly unjust exclusion of many traditional practices, makes the governance structure untenable and politically unacceptable for local people" (p.58).

In 2008 and 2009, widespread crop failures, persistent interpersonal insecurities, national political unrest, and increasing prices of staple foods amidst economic crisis led research participants to discuss the many dimensions of hardship that people living in this Bain tao lava or 'long wounded year' experienced. This period was certainly wounded; many participants felt that their ability to make a living was reaching (or had already reached) a breaking point due to at times overwhelming challenges. Even small communities with few cattle or other valuable assets set up night watches to guard against bandits and cattle thieves. Others chose to divest in livestock in order to deter banditry. Helicopters flying over the Mikea Forest region to survey the extent of Mikea Forest's titanium deposits fueled rumors that the forest had been sold to foreigners. At the same time, many worried about future consequences of the emergent national park and related environmental policies.

\section{Field sites and methodological considerations}

\section{Field sites and sampling}

Three field sites, Andalambezo, Ampijilova, and Mañono (Figure 2), were selected as research sites based on initial site visits and discussions with local elders and elected mayors in 2008. These field sites were selected to reflect regional variation in subsistence practices, local ecologies, proximity to market opportunities, and exposure to environmental policies.

Andalambezo (pop. 135) is a coastal village located just west of the buffer zone boundary of the Mikea National Park. Because Andalambezo residents maintain historical memory of forest and foraging, and practice some of the marine livelihoods associated with Vezo people, they are known locally as "VezoMikea." Residents primarily rely on markets for labor, manufactured products, and foraged marine products, but also practice small-scale farming and some terrestrial foraging. Most adults regularly travel by foot to nearby beachfront villages to practice market-oriented marine foraging. Since most do not own the equipment necessary for marine foraging (nets, canoes, diving masks, etc.), a large portion of these earnings is spent to rent equipment. Although residents frequently supplement their diets and income with foraged products from the Mikea Forest and use wood and other forest materials to construct houses and manufacture furniture, outrigger canoes, and other goods, they are not dependent on the forest in the same ways as people living in Ampijilova and Mañono, and in fact are the most dependent of the three sites on markets and a local Catholic mission for security and to satisfy dietary needs because of frequent subsistence shortfalls.

Residents of Ampijilova (pop. 112) self-identify as Mikea and people from outside the Mikea Forest region often assume that they are 'pristine foragers.' Mikea at Ampijilova are actually creative bricoleurs who maintain diverse livelihoods that include extensive horticulture, market commerce, and opportunistic wage labor in addition to hunting and gathering of wild products and freshwater fishing. Ampijilova is a small community located within protected area boundaries. As a result, of the three communities included in this project, Ampijilova is the most directly affected by environmental policies and protected area establishment;

\footnotetext{
${ }^{2}$ The use of discourses of autochthony and rurality to justify territorial exclusions in the context of Mikea Forest environmental policy is discussed in detail elsewhere (see Huff 2012).
} 
rules about residence and resource use have directly and indirectly restricted the mobility, livelihoods diversity, and ability to store wealth for people living in forest settlements like Ampijilova. Compared to residents of Andalambezo and Mañono, residents at Ampijilova are considered 'poor' and have significantly less access to missions, schools, and marketing opportunities, and because they also have less access to judiciary institutions and trustworthy security personnel feel that security is constantly at risk from banditry and extortion by corrupt rural police and people claiming to be park service authorities.

Mañono (pop. 651) is a large village in the north of the region, located about $15 \mathrm{~km}$ southeast of the colonial-era port town of Morombe, and on the northern edge of the buffer zone of the Mikea National Park. Because most residents identify as being historically Mikea and still practice some forest foraging, but rely heavily on the agropastoral way of life associated with Masikoro cultural identity, they are referred to as "Masikoro-Mikea." Residents of Mañono are economically diversified and the village has some wealth and prosperity. It also has a very high level of economic inequality. Sharecropping relations are common as a few men control much of the agricultural land, and most families living in the village consider themselves to be relatively poor because they either own very few cattle or lack full control over the productive resources that they use.

The sampling plan for each field site was based on an initial exhaustive census that members of the research team performed prior to the commencement of data collection. According to the census, Andalambezo and Ampijilova were small enough to allow exhaustive sampling, so the research team collected data among all individuals living in those sites who volunteered to participate. Because of Mañono's much larger population, the research team decided to use judgment sampling (Bernard 2000:176-178), and limited the sample to all voluntary participants who lived in households with children.

I wanted to understand how observed variation in manifestations of livelihoods vulnerability is produced in this dynamic regional context. Applying the landscape framework in this instance involved the identification of four basic categories of phenomena, and then the identification of interactions among phenomena in each category and interactions that cross categories. I identified these categories and phenomena based on qualitative content analyses of observations recorded over the course of ethnographic research and of qualitative data collected in gender-segmented focus groups $(n=4)$, oral histories $(n=20)$, semi-structured individual interviews focusing on livelihoods $(n=40)$, and daily conversations over the course of ethnographic research in 2008 and 2009. The four categories of phenomena include manifestations of livelihoods vulnerability, strategies and heuristics associated with long-term adaptability, changes that are experienced as acute stressors and challenges, and mediating actions and adjustments that people take in response to perceived acute stressors. Each category is explained.

\section{Locating manifestations of livelihoods vulnerabiltity}

The first category of phenomena includes locally and analytically salient manifestations of livelihoods vulnerability. Following Ellis (2000), I view livelihoods broadly, as comprised of diverse economic and noneconomic elements and relationships, including, among other things, capabilities, assets, material and social resources, and activities required to make a subjectively satisfying and secure living as well as the social relationships and institutions that mediate access to resources and streams of income and sustenance (Ellis 2000: 291; Yaro 2004: 27).

I chose to operationalize relative vulnerability of livelihoods in terms of an important embodied manifestation of food insecurity: the nutritional status of adults and children. Food insecurity is widely accepted by researchers as an important health indicator, and analysis of nutritional data gives insight into exposure to particular types of proximal economic and environmental stressors and can help researchers determine the magnitude of dietary stress that different individuals or groups experience in the present or may have experienced in the past (Crooks et al. 2007). Furthermore, food security is a central goal of rural livelihoods and is a locally salient indicator of individual health and livelihoods success in the Mikea Forest region. This assertion is supported by previous research that demonstrated that food insecurity is an important impoverishment risk associated with a breakdown of entitlements and capability deprivation among Mikea, Masikoro, and Vezo living in six different settlements in the Mikea Forest region (Tucker et al. 2011). 
In order to assess variation in nutritional status of adults and children, members of the research team collected standard anthropometric measurements (Frisancho 1990) among adults and children living in each field site. These measurements were iterated in two seasonal periods: the season that is locally called Listake, which is normally the hot, wet season (December-March), and Asotre, the relatively cooler, drier season (June-August). Among adult participants over 20 years of age who were neither pregnant nor nursing (395 measures for all sites in both seasons), anthropometric measurements included stature in centimeters, weight in kilograms, and waist and hip circumference in centimeters. For children aged 36 months through 12 years (297 measures for all sites in both seasons), measurements included triceps, biceps, subscapular, and suprailiac skinfolds measured in millimeters with Lange calipers, stature and mid-upper arm circumference in centimeters, and weight in kilograms. The stature of all participants was measured using a portable stadiometer, and waist, hip, and upper arm circumference were measured using a flexible tape measure. Weight was measured with a Tanita solar digital scale.

Nutritional status for adults and children were calculated using Epi Info epidemiologic analysis software with CDC 2000 references. Adult BMI was regressed on predictor variables (season, dummy variables representing field sites, sex, and age decade derived from rank-ordered age, separated into ten-year increments) in STATA 10. Individual and household level data that were used in the regression analyses were collected over the two seasons using a field-tested questionnaire that was also used to collect data on livelihoods diversification, dietary diversity, and income (these results are not presented here).

The Kruskal-Wallis equality-of-populations rank test in STATA 10 was used to assess variation in adult stature and variation in the incidence of underweight adults (BMI<18.5) by site, by sex, and by season. Variation in incidence of overweight adults was not assessed because overweight was very rare among participating adults.

For children aged 36 months through twelve years, raw data were converted to height-for-age $z$-scores (HAZ), weight-for-age z-scores (WAZ), and weight-for-height z-scores (WHZ) in Epi Info with CDC 2000 references and cut-offs. HAZ, WAZ, and WHZ $(n=297)$ were regressed against predictor variables for children (season, dummy variables representing field sites, sex, and age).

These are important and telling measures of nutritional health. Among children, low Height-for-Age (HAZ) z-scores indicate risk of stunting (HAZ of at least 2 SD below the median of the reference population). Low Weight-for-Age (WAZ) z-scores indicate risk of undernutrition (more than 2 SD below the median for the reference population). Low Weight-for-Height (WHZ) z-scores indicate risk of wasting (at least 2 SD below the median of the reference population) (WHO 1995). While stunting, indicating poor growth, is common throughout the region and offers evidence that an individual has experienced episodes of poor nutrition or prior health problems during their lifetimes, undernutrition and wasting are of primary interest to this discussion because they give us information specifically pertaining to the recent and immediate nutritional environments of children and the nutritional risks that they face. For children, being underweight is an indication of chronic weight loss, and indicates current risk of severe acute malnutrition (wasting) and poor growth (stunting). Wasting indicates acute malnutrition, which is a recent or current process of extreme weight loss, and is normally a consequence of starvation or severe disease (WHO 1995).

Identifying articulations among factors of long-term adaptability, acute stressors and challenges, and mediating actions and adjustments

The final three categories of phenomena that I identified included strategies associated with long-term adaptability, changes that are experienced as acute stressors and challenges, and mediating actions and adjustments that people take in response to perceived acute stressors. Like the first category, identification of these categories was based on qualitative content analyses of ethnographic observations recorded in field notes, data collected in gender-segmented focus groups, oral histories, semi-structured individual interviews, and daily conversations with Mikea living in Andalambezo, Ampijilova, and Mañono over the two seasonal periods of data collection.

Characteristics of long-term adaptability that I identified include factors and processes that fall within the range of individual experience, local knowledge systems, and historical memory, and are considered to be 'time tested' ways of getting by in a sometimes tough and sometimes unpredictable environment. 
Characteristics of long-term adaptability in this case include strategies like mobility, diversification, and shifting cultivation that are incorporated into production systems. These would also include residential and social strategies like seasonal mobile foraging away from home villages, building social wealth through marriage and rearing wards, and deep-forest residence. These are strategies that associated with access to particular types of productive resources and with the long-term avoidance of socio-economic discrimination, corruption, and crime.

Next, I identified processes that result in social and environmental changes that are experienced by participants as acute stressors. These are experienced or perceived as relatively rapid changes that require immediate action to avoid negative consequences. These factors are important in part because they may be novel, and also because, as they articulate with longer-term processes and strategies, these changes can constrain action and challenge peoples' capabilities to maintain wellbeing. Conversely, acute stressors can also present opportunities that facilitate resilience. In this case, such changes include weather-related hazards like prolonged drought or cyclones, economic shocks associated with changing food prices or changing resource access due to recent environmental policies, or political shocks that have rippling effects across geographic and social space.

Third, I identified actions taken by participants in response to perceived acute stressors in order to mediate effects, or adjustments to individual behavior or production systems in order to offset specific, predictable negative consequences. These actions may include alteration of cropping patterns, reducing the amount of food or types of food consumed, the adoption of mobile strategies (marketing, foraging, or wage labor), temporary or permanent changes in residence, strategic hoarding of surplus produce, resistance or avoidance of authorities, paying bribes, or hiding or divesting individual or household assets.

The final step in applying the landscape framework is to identify articulations and linkages among factors of long-term adaptability, acute stressors, and mediating actions. Health is not an outcome of linear processes, but is produced at the forefront of complex social and ecological relationships in which people are enmeshed (King and Crews 2013). Likewise, the relative security or vulnerability of rural livelihoods at any point in time, as well as particular manifestations of vulnerability, are affected by a number of interrelated factors. These factors may originate on and cross social and ecological scales, but interact to create 'pathways' that link processes to perceptive and bodily experience (Casale et al. 2009; Fraser et al. 2011; Moreda 2012; de Sherebinin et al. 2008). These linkages are mediated by context-specific factors and strategies. Therefore, identifying linkages within the constraints and possibilities of lived context allows us to gain a general understanding of why variation in vulnerability exists within a region, and also allows us to gain a nuanced understanding of why some groups and individuals are more resilient than others in the face of change.

\section{Results: understanding variation in livelihoods vulnerability in the Mikea Forest region}

I first present analyses of nutritional data that demonstrate variation in manifestations of livelihoods vulnerability across the three field sites. These results are summarized in Tables 1-4. Next, I situate these results in relation to linkages among factors of long-term adaptability, acute stressors and challenges, and mediating actions and adjustments, which are summarized in Figures 3-5. Understanding articulation among these factors and mediating effects that are specific to particular groups and localities helps understand observed variation in livelihoods vulnerability. While some of the factors and articulations identified below are exclusive to particular localities, others are experienced across the region but vary in their effect on livelihoods vulnerability because of different capabilities of different groups of people to cope with exposure to acute stressors.

\section{Variation in manifestations of livelihoods vulnerability among adults and children across three sites}

Results of linear regression analysis on the mixed longitudinal (two measures) data set $(n=385)$ show that among adults, living in the forest village of Ampijilova is associated with low BMI ( $\beta=-0.79, \mathrm{p}=0.025)$ and age decade ( $\beta=-0.37, \mathrm{p}=0.001$ ). Mean BMI among adults (Table 1 ) and the incidence of underweight 
among adults $($ BMI<18.5) (Table 2) vary by site, season, and by sex, but this variation was not statistically significant in the mixed longitudinal sample.

\begin{tabular}{|c|c|c|c|c|c|c|c|c|c|c|c|c|}
\hline & \multicolumn{6}{|c|}{$\underline{\text { Season } 1}$} & \multicolumn{6}{|c|}{ Season 2} \\
\hline & \multicolumn{3}{|c|}{ Men } & \multicolumn{3}{|c|}{ Women } & \multicolumn{3}{|c|}{ Men } & \multicolumn{3}{|c|}{ Women } \\
\hline & $n$ & $\begin{array}{c}\text { Mean } \\
\text { BMI }\end{array}$ & $S D$ & $n$ & $\begin{array}{c}\text { Mean } \\
\text { BMI }\end{array}$ & $S D$ & $n$ & $\begin{array}{c}\text { Mean } \\
\text { BMI }\end{array}$ & $S D$ & $n$ & $\begin{array}{c}\text { Mean } \\
\text { BMI }\end{array}$ & $S D$ \\
\hline Anda & 32 & 20.15 & 1.50 & 34 & 20. & 2.99 & 25 & 20 & 1.29 & 40 & 19.8 & 2.67 \\
\hline Ampijilova & 16 & 20.13 & 1.17 & 14 & 17.62 & 2.15 & 13 & 19.80 & 1.23 & 16 & 17.56 & 2.24 \\
\hline Mañono & 55 & 19.7 & 2.00 & 50 & 20.70 & 3.31 & 50 & 20.70 & 2.09 & 50 & 20.67 & 3.50 \\
\hline
\end{tabular}

Table 1: Mean adult BMI by site, sex, and season.

\begin{tabular}{|c|c|c|c|c|c|c|c|c|c|c|c|c|}
\hline \multirow[t]{4}{*}{ Field site } & \multicolumn{6}{|c|}{ Season 1} & \multicolumn{6}{|c|}{ Season 2} \\
\hline & \multirow{3}{*}{$n$} & \multicolumn{2}{|c|}{ Men } & & \multirow{2}{*}{\multicolumn{2}{|c|}{$\begin{array}{l}\text { Women } \\
\text { Underweight }\end{array}$}} & \multicolumn{3}{|c|}{ Men } & & \multirow{2}{*}{\multicolumn{2}{|c|}{$\begin{array}{l}\text { Women } \\
\text { Underweight }\end{array}$}} \\
\hline & & Unc & eight & $n$ & & & $n$ & & veight & $n$ & & \\
\hline & & $n$ & $\%$ & & $n$ & $\%$ & & $n$ & $\%$ & & $n$ & $\%$ \\
\hline And & 32 & 5 & 15.6 & 34 & 0 & 26.4 & 25 & & 12.0 & 40 & 15 & 37.5 \\
\hline Ampijilov & 16 & 1 & 6.6 & 14 & 10 & 71.4 & 13 & 1 & 7.6 & 16 & 12 & 75.0 \\
\hline Mañ̃ono & 55 & 14 & 25.4 & 50 & 13 & 26.0 & 50 & 6 & 12.0 & 50 & 12 & 12.0 \\
\hline
\end{tabular}

Table 2: Proportion of underweight adults by site, sex, and season.

When these variables were examined separately within each site, gendered patterns and changes across seasons were observed. According to results of Kruskal-Wallis equality-of-populations rank tests, in Season 1 , sex differences in underweight adults were only significant in Ampijilova $(H=9.20(1 \mathrm{DF}), \mathrm{p}=0.0024)$, where ten of eleven underweight adults were women. In Season 2, sex differences in underweight were significant in Andalambezo ( $\mathrm{H}=4.919(1 \mathrm{DF}), \mathrm{p}=0.0026)$ where fifteen of eighteen underweight adults were women, and Ampijilova ( $\mathrm{H}=12.68$ (1DF), $\mathrm{p}=0.004)$ where twelve of thirteen underweight adults were women. According to results of the Kruskal-Wallis rank test, adult stature is not significantly different among the three field sites ( $\mathrm{H}=4.58$ (2 DF), $\mathrm{p}=0.795)$.

Mean HAZ, WAZ and WHZ calculations for boys and girls are summarized in Table 3, and the percentages of boys and girls in each field site showing evidence of stunting, undernutrition, and wasting are shown in Table 4. Results of linear regression analyses of the mixed longitudinal data set $(n=256)$ indicate that among children, residence in Ampijilova is significantly associated with low HAZ ( $\beta=-0.638, p=0.009$ ), low WAZ ( $(=-1.227, p=0.000)$, and low WHZ $(\beta=-1.0, p=0.000)$. HAZ is also negatively associated with age $(\beta=-0.30, p=0.00)$ and male sex $(\beta=-0.456, p=0.007)$. Likewise, WAZ is negatively associated with age $(\beta=-0.24, p=0.00)$ and with male sex $(\beta=-0.49, p=0.004)$.

These results are discussed below in the context of each field site.

The market, the mission, and declining child nutrition in Andalambezo

In Andalambezo during the first season of data collection, about one-fourth of women and about onesixth of men were underweight and there was no statistically significant change in adults' nutritional status between seasons. However, decline in food security in Andalambezo is evidenced by increased incidence of underweight among boys and increased incidence of wasting among both girls and boys observed in the second season of data collection. Results regarding factors of long-term adaptability, acute stressors and challenges, and mediating actions and adjustments are discussed, and presented in Figure 3.

The current village of Andalambezo began as a school 'under the trees' and a food, surplus clothing, and medicine distribution site established by Catholic Missionaries in the 1960s. The site was chosen by the coastal mission because of its location as a rest stop with fresh spring water along a well-traversed path connecting traders on the eastern savanna to western coastal settlements. Over the years, a permanent mission 
outpost with a resident priest and staff was established, which, coupled with nearby opportunities for mangrove and marine foraging and the close proximity of forest-based farming opportunities, attracted transient families and settlers from other coastal and forest villages across the region.

\begin{tabular}{|ccccccc|}
\hline Field site and season & $\begin{array}{c}\text { Mean } \\
\text { HAZ }\end{array}$ & SD & $\begin{array}{c}\text { Mean } \\
\text { WAZ }\end{array}$ & SD & Mean & \\
Andalambezo, Season 1 & SD \\
\cline { 2 - 7 } Boys ( $n=13)$ & -1.627 & 1.166 & -1.558 & 0.731 & -0.755 & 1.209 \\
Girls $(n=19)$ & -1.001 & 1.660 & -1.597 & 1.418 & -1.289 & 0.718 \\
Andalambezo, Season 2 & & & & & & \\
Boys ( $n=10)$ & -0.822 & 1.097 & -1.423 & 0.774 & -1.352 & 1.299 \\
Girls ( $n=22)$ & -1.896 & 1.747 & -2.242 & 1.677 & -1.261 & 0.883 \\
Ampijilova, Season 1 & & & & & & \\
Boys ( $n=8)$ & -2.105 & 1.870 & -3.683 & 2.525 & -3.145 & 1.553 \\
Girls ( $n=12)$ & -1.570 & 1.513 & -2.023 & 1.630 & -1.315 & 1.157 \\
Ampijilova, Season 2 & & & & & & \\
Boys ( $n=6)$ & -2.126 & 2.070 & -3.321 & 1.887 & -2.615 & 1.074 \\
Girls $(n=10)$ & -1.600 & 0.911 & -1.937 & 1.716 & -1.227 & 1.261 \\
Mañono, Season 1 & & & & & & \\
Boys ( $n=36)$ & -1.790 & 1.447 & -2.036 & 1.669 & -1.082 & 1.603 \\
Girls $(n=43)$ & -0.782 & 1.302 & -1.170 & 0.968 & -1.000 & 1.105 \\
Mañono, Season 2 & & & & & & \\
Boys ( $n=38)$ & -1.702 & 1.422 & -1.705 & 1.419 & -0.687 & 1.054 \\
Girls ( $n=39)$ & -1.130 & 1.164 & -1.169 & 0.938 & -0.624 & 1.096 \\
\hline & & & & & & \\
\hline
\end{tabular}

Table 3: Boys' and girls' mean HAZ, WAZ, and WHZ by site and season.

\begin{tabular}{|c|c|c|c|c|c|c|}
\hline \multirow{2}{*}{ Field site and season } & \multicolumn{2}{|c|}{ Stunting } & \multicolumn{2}{|c|}{ Underweight } & \multicolumn{2}{|c|}{ Wasting } \\
\hline & $n$ & & & $\%$ & $n$ & $\%$ \\
\hline \multicolumn{7}{|l|}{ Andalambezo, Season 1} \\
\hline Boys $(n=13)$ & 4 & 30.7 & 2 & 16.6 & 2 & 15.3 \\
\hline Girls $(n=19)$ & 4 & 21.0 & 6 & 31.5 & 2 & 10.5 \\
\hline \multicolumn{7}{|l|}{ Andalambezo, Season 2} \\
\hline Boys $(n=10)$ & 1 & 10.0 & 2 & 20.0 & 2 & 20.0 \\
\hline Girls $(n=22)$ & 8 & 36.4 & 4 & 18.2 & 4 & 18.2 \\
\hline \multicolumn{7}{|l|}{ Ampijilova, Season 1} \\
\hline Boys $(n=8)$ & 3 & 37.5 & 7 & 87.5 & 6 & 75.0 \\
\hline Girls $(n=12)$ & 2 & 16.7 & 6 & 50.0 & 4 & 33.3 \\
\hline \multicolumn{7}{|l|}{ Ampijilova, Season 2} \\
\hline Boys $(n=6)$ & 2 & 33.3 & 5 & 83.3 & 4 & 66.6 \\
\hline Girls $(n=10)$ & 4 & 40.0 & 4 & 40.0 & 4 & 40.0 \\
\hline \multicolumn{7}{|l|}{ Mañono, Season 1} \\
\hline Boys $(n=36)$ & 19 & 52.7 & 16 & 44.4 & 10 & 27.7 \\
\hline Girls ( $(n=43)$ & 7 & 16.3 & 8 & 18.6 & 8 & 18.6 \\
\hline \multicolumn{7}{|l|}{ Mañono, Season 2} \\
\hline Boys $(n=38)$ & 17 & 44.7 & 15 & 39.5 & 5 & 13.2 \\
\hline Girls $(n=39)$ & 11 & 28.2 & 7 & 17.9 & 2 & 5.1 \\
\hline
\end{tabular}

Table 4: Proportion of boys and girls showing evidence of stunting, underweight, and wasting, by site and season.

Current residents of Andalambezo diversify their economic and subsistence portfolios, relying on a mix of mangrove and marine foraging, gardening, rearing livestock and smallstock, manufacturing, wage labor, and market commerce. In recent years, restrictions on forest-based hatsaky maize production and tree 
harvesting have reduced residents' access to land and resources used to weave baskets and sleeping mats, and to build furniture and outrigger canoes used by Vezo fishers. This has constrained subsistence and manufacturing capabilities. Large, bowl-shaped gardens maintained near the village atop the coastal limestone plain must be seasonally fertilized with manure and depend on heavy annual rains in order to be productive and produce starchy staple foods like maize and manioc. Frequent subsistence shortfalls are locally attributed to a scarcity of land for sufficient agricultural production, and residents are dependent on markets for food due primarily to this historical resource scarcity. Revenue from marine foraging, wage labor, and manufacturing are used to rent equipment used for marine foraging and to supplement what households produce with purchased maize, rice, and beans from the local Catholic mission, and manioc from mobile retailers that travel from the savanna to the coast to sell produce.

Prolonged drought in 2008 and 2009 resulted in crop failure and caused adverse conditions for marine foraging. This meant that residents of Andalambezo were more dependent than usual on markets for food, especially starchy staples. The inception of national political and economic crises in 2009 was followed by rising prices of staples and with increased security risk for food transporters. This conjuncture of factors proved problematic for market-dependent people because the availability of starchy staples to purchase declined in an absolute sense while costs for what was available nearly tripled in less than two months in 2009. Hunger became a daily worry in Andalambezo, and poor food access affected childrens' bodies most dramatically.

\section{Phenomena associated with declining child nutritional status in Andalambezo}

\section{Eactors of long-term adaptability:}

- Economic diversification, including farming, market- and subsistence-oriented marine foraging, wage labor, livestock and smallstock

- Mission presence conveys security from corruption and theft; facilitates access to food and medicine

- Coastal residence gives access to marine resources, livelihood opportunities

Acute stressors:

- Environmental policies and induced scarcity of natural resources: prohibition of hatsaky maize production; restricted access to other forest resources used in manufacturing

- Prolonged drought results in insufficient rain for gardening; poor quality of drinking water

- 2009 political and economic crises result in rising food prices; increased crime on trade routes results in scarcity of food for purchase due to transport risk

Articulations, actions, and adjustments:

- Prolonged drought and environmental policies: increase home gardens; bucket irrigation; mobile wage labor

- 2009 political and economic crises and drought led people to remain near mission for security; to purchase cheap staple food for high prices; to increase mangrove foraging for subsistence

Figure 3: Factors of long-term adaptability, acute stressors and challenges, and mediating actions and adjustments in Andalambezo. 
Several residents explained that Andalambezo was not a good place to live because of subsistence problems, scarcity of 'healthy water,' and great distance from regional commerce centers and biomedical health care facilities. At the same time, these participants felt that the security benefits of the local mission were an inducement for people to remain in Andalambezo despite hunger and economic challenges. Participants explained that the mission provides security against opportunists like corrupt police demanding bribes and against armed banditry, both of which were widely feared throughout the region. Many tried to cope by increasing the size of home gardens that could be bucket-irrigated with well water, by increasing mangrove foraging activities for home consumption, and (among men) by participating in mobile wage labor away from the village. Yet women, particularly mothers with young children, discussed difficulties providing sufficient food for daily consumption and a sense of feeling 'trapped' in a village with insufficient local resources for independent subsistence.

\section{Absolute scarcity and social insecurities in the forest village of Ampijilova}

The most severe manifestations of livelihood vulnerability were observed in Ampijilova. The highest proportion of underweight adults and lowest BMI across the mixed longitudinal sample was observed at Ampijilova, where adult undernutrition is highly gendered. At Ampijilova, nearly all women, most of whom are of reproductive age, are underweight. Across the sample, stunting, underweight, and wasting among children are significantly associated with residence in Ampijilova, where children aged 36 months to 12 years were, compared to children living in the two other sites, disproportionately underweight and/or manifested wasting. In both seasons of data collection, approximately two-thirds of children aged 36 months through 12 years were underweight, and half showed evidence of wasting in both seasons. Factors of long-term adaptability, acute stressors and challenges, and articulations, actions and adjustments are presented in Figure 4.

Since the pre-colonial period in southwestern Madagascar, forest-based residence has been a strategy used to avoid hunger and elite forms of authority associated with violence and exploitive social relationships. Among elder oral historians living in Ampijilova and other forest villages, remote residence is a long-term strategy that is desirable because it facilitates subsistence independence through foraging and extensive horticulture, and allows people to avoid institutionalized discrimination and crime (see Huff 2011; Kelly and Poyer 1999; Tucker 2003; Yount et al. 2001). Despite these benefits, forest residence involves trade-offs. Due to geographic distance residents at Ampijilova have less access to missions, biomedical clinics, schools, agricultural development projects, and market goods. Compared to residents of Andalambezo and Mañono, residents of Ampijilova are materially poor, generally posessing substantially less money, furnishings, animals, and other material property. When in larger towns and villages, they are often stigmatized for being dirty, a result of tuber foraging, or wearing tattered clothing. Mikea lack political power in the broader region and are more likely than members of other identity groups to be harassed by police, cheated in commerce, or cheated when engaging in wage labor (Tucker et al. 2011).

Marked seasonality of rainfall and in availability of wild foods in forest means that lean periods are common among people who live forest-based lifestyles. But seasonal dryness and sporatic periods of drought are very different from the prolonged drought experienced in the region during the research period. Mikea have long-practiced activities in order to counter the negative effects brief or periodic scarcity. These include subsistence diversification, selling material assets or livestock, opportunistic engagement with markets for export 'booms' of wild silk and hatsaky maize, seasonal wage labor, and seasonal residential fissioning in which families temporarily leave permanent villages to live in smaller foraging or farming camps in areas of low population density. Residents of Ampijilova who depend on forest forage and horticulture of maize, sweet potatoes, and other crops were doubly affected by water scarcity in 2008 and 2009; in addition to a lack of water for cultigens, wild foraged foods including honey, various wild fruits, a nutritious tuber called ovy [Discorea acuminata], and a watery tuber called babo [Discorea bemandry] failed to thrive in parts of the forest as well.

In recent years, evolving regional environmental policies have constrained economic and residential opportunities among forest-based Mikea. As a result on the prohibition of hatsaky maize production, Ampijilova's residents have drastically reduced maize production within the forest because of fear of fines and 
harassment by people claiming to be lehibe anala, or "forest police." The direct effect of this is the elimination for many of their largest source of cash income and greatly reduced production of the most nutritious non-foraged and storable staple food. Mikea at Ampijilova also feel that they have become more vulnerable to banditry and cattle theft since the advent of the hatsaky maize ban, and in response to this perceived risk residents of Ampijilova and some other forest communities have hidden cattle ownership or divested in herds as a means to protect themselves from the attention of criminals. For Mikea who have abandoned even very small cattle stocks, this has meant removing the most significant form of wealth storage and a means of ensuring economic security in lean times for the sake of security against violence and theft. Due to absolute scarcity, many residents of Ampijilova chose to abandon forest residence and move to more populous areas in search of opportunities for wage labor. During the first season of data collection, many people who remained subsisted for days on end eating foraged honey mixed with hot water (a meal that makes one feel full in the short-term but ultimately leaves one fatigued and can cause stomach pain) and the occasional freshwater fish. By Season 2 most residents who were physically able had resorted to long-term mobile foraging; people who remained in their homes included the very elderly, the very young, and women with young infants.

\section{Phenomena associated with Absolute scarcity and social insecurities in the forest village of Ampijilova \\ Factors of long-term adaptability \\ - Forest-based primary residence to ensure subsistence security through wild resources and horticulture; avoid state violence and institutionalized discrimination; security from corruption and theft \\ - Seasonal mobility and periodic residential fissioning creates options mobile foraging and farming in 'lean seasons'; seasonal camps reduce population density around villages and allow access land and resources away from primary residence \\ - Economic diversification and opportunism, including foraging, freshwater fishing, farming, market commerce, rearing and selling livestock and smallstock, participating in market 'booms' for various products}

Acute stressors:

- Environmental policies and induced scarcity of natural resources: prohibition of hatsaky maize production; limitation of foraging range; restriction on residence and mobility; increased exposure to crime and corruption by rural police and parks service representatives

- Prolonged drought resulted in insufficient rain for horticulture and failure-to-thrive of wild forage

Articulations, actions, and adjustments:

- Prolonged drought and environmental policies led people to restrict food intake to make resources last longer; people made permanent residential shift to larger villages, wage labor, or long-term mobile foraging

- Environmental policies, crime, and institutionalized discrimination led people to reduce/eliminate maize production to avoid bribes and harassment; to pay bribes; to increase manioc grown in gardens near village; divest of livestock

Figure 4: Factors of long-term adaptability, acute stressors and challenges, and mediating actions and adjustments in Ampijilova.

Adaptability in crisis and improving nutritional status among adults and children in Mañono

While residents of Mañono faced hardship in the long, wounded year, livelihoods were more resilient to acute stressors than those in Andalambezo or Ampijilova. Among residents of Mañono, the likelihood of being 
underweight among adults in Mañono was not gendered in the first season of data collection; about onequarter of adult men and women were observed to have low BMI. This rate remains the same for women in the second season, but incidence of underweight among adult men dropped to only about 12 percent. Among boys in Mañono, observed rates of underweight remained relatively constant between seasons, but observed rates of wasting are halved in the second season. Among girls, observed rates of underweight remain relatively constant, and rates of wasting fall by about seventy-five percent between the first and second season of data collection. Factors of long-term adaptability, acute stressors and challenges, and mediating actions and adjustments are discussed below and presented in Figure 5.

Mañono, established in the 1930s by Mikea who migrated from forest villages in response to colonialera resettlement policies, is a large, formally chartered village located in close proximity to the Mikea Forest and permanent markets in the nearby seaside town of Morombe. The village has formal collective rights to high-quality agricultural land, woodlots for charcoal manufacture, and fresh water springs for irrigation and consumption. At the village level, residents of Mañono are extremely economically diversified and satisfy subsistence needs by keeping livestock, farming starchy staple crops (paddy rice, maize, and manioc), vegetables, and fruits, and selling excess produce and locally produced charcoal in the permanent marketplace in Morombe. Many residents are also economically specialized, engaging in skilled carpentry, licensed and illicit rum production, tool repair, sewing, and oxcart baggage transport.

\title{
Phenomena associated with adaptability and improving nutritional status among adults and children in Mañono
}

\author{
Factors of long-term adaptability \\ - Economic diversification, including market- and subsistence-oriented farming, skilled wage labor and \\ manufacture; livestock and smallstock; charcoal production \\ - Residence in proximity to permanent markets and forest resources; secure entitlements \\ - Security from resident security personnel and local militia
}

Acute stressors:

- Environmental policies induced scarcity of natural resources; hatsaky maize prohibition; restriction of legal access to woodlots

- Prolonged drought reduced crop yields; poor drinking water quality

- 2009 political and economic crises and drought resulted in rising food prices, increased highway crime and difficulty selling 'luxury' (non-staple) produce

Articulations, actions, and adjustments:

- Environmental policies: Obtain legal access to new woodlots

- 2009 political and economic crises and crime led people to travel to market in large groups or with armed escort

- Drought resulted in altered cropping patterns, especially for irrigation-intensive paddy rice

- 2009 political and economic crises and drought led some to hoard-and-sell surplus staple crops (maize, manioc, and rice)

Figure 5: Factors of long-term adaptability, acute stressors and challenges, and mediating actions and adjustments in Mañono.

In the past, residents of Mañono have engaged in lucrative hatsaky maize production, but because of secure access to irrigated agricultural land are not dependent on hatsaky for primary subsistence or cash flow. 
Charcoal production, which is particularly important to Mañono's economy but is contingent on legal access to woodlots, has been affected by protected area rules. There has been confusion among households that dominate local charcoal production regarding procedures for gaining legal title to productive woodlots, and distress caused by the unexplained and uncompensated seizure of oxcart loads of charcoal by police stationed along the road to market in Morombe. Yet, in 2009 local politicians were in the process of determining proper bureaucratic procedures for securing rights to maintain new productive woodlots.

Despite the high quality of soil and an abundance of springs surrounding the village, residents have been affected by drought and rising food prices, but different people have been affected in different ways. In Mañono, where rice, maize, and other crops are irrigated by rainfed and spring-fed canals, approximately onethird of paddy rice fields lay unplanted in 2009 due to water scarcity and many farmers complained of losing whole fields of immature pulses and vegetables to drought.

While many complain of the risk of hunger, a lack of dietary diversity, and an inability to sell produce (especially tomatoes and other vegetables) in the permanent marketplace at Morombe, people generally are able to meet subsistence needs. Others have profited greatly by strategically hoarding and selling starchy staple crops — surplus maize, manioc, and rice-in the period of urban food shortage following the beginning of the national political crisis in 2009. Residents feel that the village itself is relatively secure due to the fact that several residents are members of the military and rural police and that the village has a volunteer 'militia'. But, despite potential income from strategic market engagement, residents are hesitant to travel to market on the long road to Morombe without an armed escort because the incidence of mobile banditry has increased with the rise in food prices and urban food insecurity.

\section{Discussion}

Through the identification of how strategies and heuristics associated with long-term adaptability, acute stressors and challenges, and mediating actions and adjustments that people take in response to perceived acute stressors are associated with salient manifestations of vulnerability, a landscape approach presents an integrative means of situating the production of health at the forefront of historical structural, ecological, and agential processes and interactions. At the same time, a multi-site comparative approach facilitates the examination of how conjunctures among cross-scalar phenomena contribute to variation in the experience of relative vulnerability and resilience.

The idiom of the Bain tao lava, 'the long, wounded year,' and worries associated with livelihoods and food insecurity were expressed and understood across the Mikea Forest region during the research period. As stated in the introduction, this was a period of "conjunctural vulnerability" (Ribera and Hausman-Muela 2011: 110), characterized by the syndemic confluence of often adverse ecological and sociopolitical circumstances. A number of these circumstances were a matter of common experience across the region. Long-standing environmental and political challenges were exacerbated by a number of new challenges. Prolonged drought affected marine conditions, croping patterns, the viability of cultigens, the distribution and abundance of wild resources, and worries about subsistence shortfalls. Restrictive environmental policies restructured smallholders' customary and formal entitlements, induced natural resource scarcity, created new modes of policing and corruption, and affected the composition of economic portfolios and the dietary availability of important foods. National political events and related urban food shortages affected non-subsistence activities, and, through rising food prices and increased risk of transporting goods to market, affected the accessibility of market goods to supplement subsistence shortfalls.

However, the precise ways and magnitude in which these circumstances were experienced among different groups of people, and precise effects on livelihood capabilities, coping possibilities, and human bodies was quite variable between and within sites examined. This is why I argue that conceptualizing vulnerability as an emergent characteristic of lived context and focusing analytic attention on how different identifiable processes articulate and focus risk in different ways for different groups of people can help us better understand how variation in health is produced in dynamic settings. In this regional comparison, longterm challenges and factors of adaptability articulate with acute stressors and possibilities for mediating action. These articulations, or dialectical linkages among processes, create emergent forces that are qualitatively distinct from 'the sum of their parts.' In other words, as multiple long-standing and acute 
circumstances and stressors and context-specific factors and strategies articulate, spaces of vulnerability emerge.

In this comparison, spaces of vulnerability coincide with geographic space because different villages have unique social and settlement histories, over time people have developed bricolage livelihood strategies based on ecological particularities, and people experience different social and spatial proximities to state policies, markets, educational opportunities, and other resources.

At the same time, if analytic attention shifts to particular questions about variation in nutritional status within sites or among different age groups, we see that different 'spaces' can be discerned. For example, if we ask why adult undernutrition is more gendered among people living at Ampijilova than at the other sites, understanding local notions of adult gender roles becomes important. When mobile farming, mobile foraging, or mobile labor strategies become necessary, elderly people, chronically sick people, and women with young children may be compelled to remain in home villages in resource-poor areas due to village security or individual physical circumstances.

Likewise, if we ask why, among children, being underweight is associated with male gender across the three sites, we must consider gendered labor roles among older children in addition to more general patterns of nutrition restriction. In the Mikea Forest region, people of all ages past infancy make important contributions to the household economy (Tucker and Young 2005) and as children grow up they learn how to be adults by taking on specific household tasks in relation to livelihoods. Older girls often stay near the home during the day, tending younger siblings, doing laundry, caring for smallstock, processing and preparing food, and have more opportunities for eating throughout the day. Older boys, on the other hand, have less access to food during their daily activities because they tend to work away from the home for long periods, often guarding browsing herds of zebu cattle away from home villages.

A landscape approach to understanding vulnerability is practically relevant in that it facilitates integrative attention to material and discursive linkages that comprise reciprocal health-society-environment relationships (King 2010; King and Crews 2013). Such frameworks can help deconstruct pervasive stereotypes that gloss complexities of rural life and livelihood, and offer means to develop empirically based alternatives to 'received wisdoms' about people, economies, and human-environment relationships that often guide development policies and practice and may result in substantial risk of harm. For example, according to regional environmental policies, forest-based Mikea live in adaptive ecological balance with the Mikea Forest as pristine foragers (WWF 2003; Repoblikan'i Madagasikara 2010). Rules regarding residency and resource use were developed based on the false association of Mikea social identity, forest residence, exclusive foraging lifestyle, and primitivism. Because the assumptions that have guided policies have been based largely on myths about Mikea people in particular and hunter-gatherer peoples more generally, policies that have been gradually put into practice have put Mikea in an increasingly untenable position in regards to meeting both short- and long-term livelihood goals. As a result, forest-based Mikea have increasingly been compelled to choose between abandoning their homes, increasing risk of food insecurity due to limiting diversification in economic portfolios, and/or attracting the attention of police and park authorities by continuing clandestine production activities. The popular and policy narrative of Mikea living in ecological balance with the forest environment, as translated into policy and practice, has amplified both sociopolitical and ecological precarity of forest life. Simultaneously, these same policy narratives are discursively juxtaposed with textual imagery that portrays other smallholders living in the region in terms of invasiveness and environmental predation that threatens both the Mikea Forest and Mikea people, justifying their exclusion from important cultural and material resources (Huff 2012). These findings have important further implications for understanding how discursive constructions of culture, local knowledge, ecology, and human rights are mobilized in international aid agreements and the creation and management of protected areas.

A landscape approach to vulnerability is also practically relevant because it can help us understand the production of resilience in a region. On the village level, residents of Mañono fared better in terms of livelihoods and nutrition than residents of Andalambezo or Ampijilova despite drought, policy restrictions on resource access, and the rippling effects of national economic and political crises. While residents of Andalambezo were almost totally dependent on troubled markets for nutritional needs and residents of Ampijilova were dependent on provisioning through foraging and extensive horticulture, residents of Mañono 
were not market dependent, but rather lucratively and opportunistically engaged with markets while at the same time maintaining self-sufficiency in subsistence. This is because collective rights to resources, interpersonal security, and proximity to markets allowed residents to generally meet the short-term goals of satisfying subsistence needs and avoiding impoverishment risks, while still contributing to long-term goals of building multidimensional wealth (cattle, productive security, families). From these results, one might hypothesize that in this region characterized by poor infrastructure and widespread distrust of the state and international development programs, livelihood resilience is associated with multiple viable options for opportunistic market engagement while maintaining subsistence security.

\section{Conclusions}

In presenting the landscape framework to explain variation in livelihoods vulnerability in the 'long wounded year' in southwestern Madagascar, I have sought to contribute to the theorization of the relational production of health at the intersection of bodily, political economic, and ecological processes. I have done this through extending and clarifying concepts and models for applying political ecological theory to questions of health and economic wellbeing. By emphasizing process and articulation, the landscape framework allows the analytic integration of scales of socio-ecological interaction, and demonstrates how the integration of ecological and social dimensions of experience can help to unmask processes that create vulnerability and may contribute to resilience in a regional context.

The relative security or vulnerability of rural livelihoods, as well as particular manifestations of vulnerability, are affected by a number of interrelated factors and changes that present significant challenges to researchers, policymakers, and especially to 'local people' (Casale et al. 2009; Fraser et al. 2011; Moreda 2012). Variation in food insecurity and nutritional status should be understood as embodied biocultural phenomena produced in dynamic political-ecological contexts. In addition, by drawing on biocultural and critical perspectives on variation and change, we can continue to develop conceptual tools to effectively identify interactions and synergies that focus exposure to multiple stressors and risk of harm in particular contexts. Frameworks that are designed to explore contextual dimensions of human security and vulnerability are a promising way to develop our theoretical understanding of dynamic change, and to increase beneficial effects of human development efforts across regions. Contextual approaches facilitate nuanced, locally salient, and experientially grounded understandings of variation in adaptability and wellbeing, while substantively incorporating issues related of framing, positionality, representation, and discourse.

The significance of the proposed landscape approach is that it can allow researchers to examine variation in health at the forefront of complex social and ecological relationships. Identifying articulations among processes that result in variation in biocultural experience gives us a better understanding of why variation in vulnerability exists within regions, and why some people are more resilient than others in the face of challenges and changes. Contexts are not static but constantly shifting. By understanding such interactions and synergies, we can begin to conceive of possibilities for new interactions and synergies that increase adaptability, security, and wellbeing in the face of change (Hadley et al. 2009; Liecheinko and O'Brien 2008; O'Brien et al. 2009). Because the landscape approach is methodologically flexible and amenable to collaborative interdisciplinary research, it can be applied to understanding how variation in vulnerability and health are produced in diverse rural and urban research contexts, and advance the goal of developing an integrated and interdisciplinary 'realm of theory and practice' (King and Crews 2013: 280-286).

\section{References}

Adger, W.N. 2006. Vulnerability. Global Environmental Change 16 (1):268-281.

Aubry, C. and A. Ramaromisy. 2003. Typology of farms in a village of the pioneer settlement area of the Mikea Forest (South West of Madagascar). Cahiers Agricultures 12 (3):153-165.

Baer, H.A., M. Singer and J.H. Johnsen. 1986. Toward a critical medical anthropology. Social Science and Medicine 23 (2):95-98.

Baro, M. and T. Deubel. 2006. Persistent hunger: perspectives on vulnerability, famine, and food security in sub-Saharan Africa. Annual Review of Anthropology (35):521-538. 
Batterbury, S.P.J.. 2001. Landscapes of diversity: a local political ecology of livelihood diversification in south-western Niger. Cultural Geographies [Ecumene] 8 (4):437-464.

Bernard, H.R. 2000. Social research methods: qualitative and quantitative approaches. Newbury Park: Sage Publications.

Blaikie, P.M. 1999. A review of political ecology: issues, epistemology and analytical narratives. Zeitschrift für Wirtschaftsgeographie 43 (3-4):131-147.

Blaikie, P.M. and H.C. Brookfield. 1987. Land degradation and society. London: Methuen.

Blanc-Pamard, C. 2009. The Mikea Forest under threat (southwest Madagascar): How public policy leads to conflicting territories. Field Actions Science Report 3 (1).

Brooks, N., Adger, W.N. and P.M. Kelly. 2005. The determinants of vulnerability and adaptive capacity at the national level and the implications for adaptation. Global Environmental Change 15 (1):151-163.

Carney, M.A. 2014. The biopolitics of 'food insecurity': towards a critical political ecology of the body in studies of women's transnational migration. Journal of Political Ecology 21: 1-18.

Casale, M., Drimie S., Quinlan T. and G. Ziervogel. 2009. Understanding vulnerability in southern Africa: comparative findings using a multiple-stressor approach in South Africa and Malawi. Regional Environmental Change (10):157-168.

Crooks, D., Cliggett L. and S. Cole. 2007. Child growth as a measure of livelihood security: the case of the Gwembe Tonga. American Journal of Human Biology 19 (1):669-675.

De Sherbinin, A., VanWey L.K., McSweeney K., Aggarwal, R., Barbieri A., Henry, S., Hunter, L.M. and W. Twine. 2008. Rural household demographics, livelihoods and the environment. Global Environmental Change 18 (1):38-53. draft

DuPuy, D. and J. Moat. 1998. Vegetation mapping and classification in Madagascar (using GIS): implications and recommendations for the conservation of biodiversity. In C. R. Huxley, J. M. Lock and D. F. Cutler (eds.) Chorology, taxonomy and ecology of the African and Madagascan floras. Kew: Royal Botanic Gardens.

Durbin, J., Ratsirarson J., Ranaivonasy J. and H. Raharijanahary. 2006. Gouvernance des aires protégées à Madagascar : réalités, atouts et contraintes. Terre Malagache/Tany Malagasy 25 (1):47-82.

Eakin, H. and A. Lynd Luers. 2006. Assessing the vulnerability of social-environmental systems. Annual Review of Environmental Resources 31:365-394.

Ellis, F. 2000. Rural livelihoods and diversity in developing countries. Oxford: Oxford University Press.

Few, R. 2007. Health and climatic hazards: framing social research on vulnerability, response and adaptation. Global Environmental Change 17:281-295.

Few, R. and P.G. Tran. 2010. Climatic hazards, health risk and response in Vietnam: case studies on social dimensions of vulnerability. Global Environmental Change 20:529-538.

Fraser, E., Dougill, A., Hubacek K., Quinn C., Sendzimir J. and M. Termansen. 2011. Assessing vulnerability to climate change in dryland livelihood systems: conceptual challenges and interdisciplinary solutions. Ecology and Society 16 (3):3.

Frisancho, R. 1990. Anthropometric standards for the assesment of growth and nutritional status. Ann Arbor: University of Michigan Press.

Hadley, C., Belachew, T., Lindstrom D. and F. Tessema. 2009. The forgotten population? Youth, food insecurity, and rising prices: implications for the global food crisis. NAPA Bulletin 32 (1):77-91.

Huff, A.R. 2011. Vulnerability and wellbeing in the baintao lava, 'the long wounded year': environmental policy, livelihoods, and human health among Mikea of southwest Madagascar. Ph.D. dissertation. Athens, USA: The University of Georgia.

- 2012. Exploring discourses of indigeneity and rurality in Mikea Forest environmental governance. Madagascar Conservation and Development 7 (2S):58-69.

Hughes, C.C., and J.M. Hunter. 1970. Disease and 'development' in Africa. Social Science \& Medicine 3 (1):443-493. 
Kelly, P. M., and W.N. Adger. 2000. Theory and practice in assessing vulnerability to climate change and facilitating adaptation. Climatic Change 47:325-352.

King, B. 2010. Political ecologies of health. Progress in Human Geography 34 (1):38-55.

King, B., and K. Crews. 2013. Challenges and opportunities for future ecologies and politics of health. In B. King and K. Crews (eds.) Ecologies and politics of health. New York: Routledge.

Leatherman, T. 2005. A space of vulnerability in poverty and health: political ecology and biocultural analysis. Ethos 33 (1):46-70.

Leatherman, T., Goodman, A. and B. Thomas. 1993. On seeking common ground between medical ecology and critical medical anthropology. Medical Anthropology Quarterly 7 (2):202-207.

Leichenko, R and K. O'Brien. 2002. The dynamics of rural vulnerability to global change: the case of Southern Africa. Mitigation and Adaptation Strategies for Global Change (7):1-18.

Levins, R. and R. Lewontin. 1985. The dialectical biologist. Cambridge: Harvard University Press.

Mayer, J. 1996. The political ecology of disease as one new focus for medical geography. Progress in Human Geography 20 (4):441-456. 2000. Geography, ecology, and emerging infectious diseases. Social Science \& Medicine 50:937-952.

Meade, M.S. 1977. Medical geography as human ecology: the dimension of population movement. Geographical Review 67 (4):379-393.

Milleville, P., Grouzis M., Razanaka, S. and M. Bertrand. 2001. La culture pionniere du maîs sur abattisbrulis (hatsaky) dans le sud-ouest de Madagascar. In S. Razanaka, M. Grouzis, P. Milleville, B. Moizo and C. Aubry (eds.) Sociétés paysannes, transitions agraires, et dynamiques écologiques dans le sudouest de Madagascar. Antananarivo: CNRE/IRD.

Moreda, T. 2012. Vulnerability, land, livelihoods and migration nexus in rural Ethiopia: a case study in South Gondar Zone of Amhara Regional State. The Hague: International Institute of Social Studies. (PhD research design)

Morgan, L.M. 1987. Dependency theory in the political economy of health: an anthropological critique. Medical Anthropology Quarterly 1 (2):131-154.

Neumann, R.P. 2011. Political ecology III: theorizing landscape. Progress in Human Geography 35 (6):843850.

O'Brien, K., T. Quinlan, and G. Ziervogel. 2009. Vulnerability interventions in the context of multiple stressors: lessons learned from the Southern Africa Vulnerability Initiative. Environmental Science and Policy 12 (1):23-32.

O'Brien, K., Eriksen S., Nygaard L. and A. Schjolden. 2007. Why different interpretations of vulnerability matter in climate change discourses. Climate Policy 7 (1):73-88.

O'Brien, K., Eriksen S., Schjolden A. and L. Nygaard. 2005. What's in a word? Conflicting interpretations of vulnerability in climate change research. Blindern: Center for International Climate and Environmental Research.

Poyer, L. and R.L. Kelly. 2000. Mystification of the Mikea: constructions of foraging identity in southwest Madagascar. Journal of Anthropological Research 56:162-185.

Repoblikan'I Madagasikara, des Eaux et Forets, Ministere de l'Environnement, and Madagascar National Parks. 2010. Plan de developpement de la population autochtone Mikea. Antanananrivo: World Bank.

Ribera, J.M. and S. Hausman-Muela. 2011. The straw that breaks the camel's back: redirecting health-seeking behavioral studies on malaria and vulnerability. Medical Anthropology Quarterly 25 (1):103-121.

Schell, L. 1997. Culture as a stressor: a revised model of biocultural interaction. American Journal of Physical Anthropology 102 (1):67-77.

Scoones, I.. 2009. Livelihoods perspectives and rural development. Journal of Peasant Studies 36 (1):171196.

Seddon, N., Tobias J., Yount J., Ramanampamonjy J., Buchart S. and H. Randrianizahana. 2000. Conservation issues and priorities in the Mikea Forest of south-west Madagascar. Oryx 34 (4):287-304. 
Singer, M. 1996. Farewell to adaptationism: unnatural selection and the politics of biology. Medical Anthropology Quarterly 10 (4):496-515.

- 2013. Respiratory health and ecosyndemics in a time of global warming. Health Sociology Review 22:98-111.

Sumner, A. and R. Mallett. 2011. Snakes and ladders, buffers and passports: rethinking poverty, vulnerability and wellbeing. Working Paper 83. Brasilia: International Policy Centre for Inclusive Growth.

Tehrani, M. 2010. The ingredients of change: a political ecology approach to diabetes in the Somali community of Minnesota. In Capstone Projects, Paper 4. Macalester College.

Tucker, B. 2003. Mikea origins: relics or refugees? Michigan Discussions in Anthropology 14:193-215.

Tucker, B., Huff A.R., Tsiazonera, Tombo J., Hajasoa P., and C. Nagnisaha. 2011. When the wealthy are poor: poverty explanations and local perspectives in southwestern Madagascar. American Anthropologist 113 (2):291-305.

Turshen, M. 1977. The political ecology of disease. Review of Radical Political Economics 9 (1):45-60.

— 1984. The political ecology of disease in Tanzania. New Brunswick: Rutgers University Press.

Walker, P.A. 2003. Reconsidering 'regional' political ecologies: toward a political ecology of the rural American West. Progress in Human Geography 27 (1):7-24.

Watts, M.J. and H.G. Bohle. 1993. The space of vulnerability: the causal structure of hunger and famine. Progress in Human Geography 17 (1):43-67.

Wingen, A. 2011. Environmental protection in Madagascar: an evaluation of program viability. M.S. thesis. Minneapolis, USA: The University of Minnesota.

World Wildlife Fund (WWF). 2003. Cadre strategique pour le developpement des populations autochtones Mikea. Antananarivo, Madagascar: World Bank and the République de Madagascar.

Yaro, J. 2004. Theorizing food insecurity: building a livelihood vulnerability framework for researching food insecurity. Norwegian Journal of Geography 58: 23-37.

Yount, J, Tsiazonera, and B. Tucker. 2001. Constructing Mikea identity: past or present links to forest and foraging. Ethnohistory 48 (1-2):257-291.

Zimmerer, K. 1999. Overlapping patchworks of mountain agriculture in Peru and Bolivia: toward a regionalglobal landscape model. Human Ecology 27 (1):135-165. 